\title{
21. \\ VLADAN DESNICA U DOKUMENTIMA \\ SAVEZA KNJIŽEVNIKA JUGOSLAVIJE
}

\section{Bojan Đorđević}

UDK: 821.163.42Desnica, V.:061.2Savez književnika Jugoslavije

Izvorni znanstveni članak

Sažetak: U radu se razmatraju aktivnosti Vladana Desnice kao člana Saveza književnika Jugoslavije, te priroda njegovih veza sa tom krovnom književnom organizacijom u tadašnjoj zajedničkoj državi. Ističu se najvažniji momenti Desničine aktivnosti vezani prevashodno za društveni i socijalni položaj pisaca i zalaganje za dostojan status tzv. profesionalnih književnika. Donose se sasvim novi podaci o učešću Vladana Desnice na kongresima Saveza književnika Jugoslavije, posebno onom održanom u Beogradu 1958. godine.

Ključne reči: Vladan Desnica, Savez književnika Jugoslavije, kongresi književnika, Almanah, kulturna politika

\section{I.}

7 T biografijama Vladana Desnice samo se retko, uzgred, i kao opštepoznata činjenica, pominje da je od 1949. godine bio član Društva književnika Hrvatske, a od sledeće godine i član Saveza književnika Jugoslavije. Isto to čita se i u dosad najdetaljnijoj biografiji:

U Društvo književnika Hrvatske primljen je potkraj 1949. godine, a u Savez književnika Jugoslavije 1950. i njegova se aktivnost u toj organizaciji ogledala u sudjelovanju na kongresima Saveza. ${ }^{1}$

No, ni ovi podaci nisu sasvim precizni. Naime, treba reći da je u tim prvim poratnim godinama Savez književnika Jugoslavije bio, rečima Marina Franičevića na jednom Plenumu te organizacije, „savez članova, a ne savez udruženja“, ${ }^{2}$ dakle centralizovana organizacija, bez čije konačne potvrde književnik nije mogao biti ni član svoje republičke organizacije. Republička organizacija je samo slala svoje mišljenje Savezu književnika Jugoslavije, a on je donosio konačnu odluku o prijemu. ${ }^{3}$ Tek ako bi ta odluka bila pozitivna, književnik bi

1 Dušan Marinković, „Biografija Vladana Desnice“, u: Vladan Desnica, Hotimično iskustvo (prir. Dušan Marinković), Zagreb 2006., 233.

2 Arhiv Jugoslavije (dalje: AJ) 498-F-12.

3 Dobar primer za to jeste namera Društva književnika Hrvatske da u to doba prokazanog Tina Ujevića primi u organizaciju. Društvo književnika Hrvatske o tome je moralo da obavesti Savez književnika Jugoslavije i da zatraži sa- 
postajao član savezne organizacije, a samim tim i svoje matične organizacije. To je, uostalom, bilo precizirano odredbom Statuta Saveza književnika Jugoslavije:

Člana republičkog društva prima u načelu [podvukao B. Đ.] Glavni odbor tog društva, a potvrđuje ga, na osnovu obrazloženog predloga, godišnja skupština Saveza književnika Jugoslavije, nakon čega on postaje član obaju društava. ${ }^{4}$

Tako se, naravno, postupilo i u Desničinom slučaju. Na sednici Društva književnika Hrvatske, održanoj 22. septembra 1949. godine, doneta je odluka o „načelnom prijemu druga Vladana Desnice, rođ. 1905. u Zadru, u članstvo Društva književnika Hrvatske“ i zaključeno da se ta odluka, sa obrazloženim predlogom, pošalje Savezu književnika Jugoslavije. To je učinjeno dva meseca docnije, 20. novembra 1949. godine. Predlagač je bio Slavko Kolar, tadašnji predsednik Društva književnika Hrvatske:

Književni rad druga Vladana Desnice poznat mi je tek u novije doba, poslije Oslobođenja. Taj rad nije opsežan, ali je značajan, te je svojom književnom i umjetničkom kvalitetom svratio na se odmah pažnju naše javnosti. Desnica je štampao u „Republici“ novele: „Susjedi“ (zapravo odlomak veće pripovijetke), te „Pred zoru“, jedna i druga sa tematikom iz vremena borbe i poslije Oslobođenja. U „Hrv. Kolu“ štampao je novele „Oko“ i „Zlatni rudnik“ sa predratnom tematikom, dok je u „Ilustrovanom vjesniku“ objavio „Cranpette“ i „Nobelovac“, isto iz predratnog vremena. Sada je predao Nakladnom zavodu Hrvatske roman iz okupacije pod naslovom „Zimsko ljetovanje“, koji je redaktor NZH ocijenio kao vrlo dobru prozu. Vladan Desnica je čovjek od oko 40 godina, znatne književne kulture i nesumnjivo talentiran pisac. Njegove su novele protkane finim humorom, napisane čistim, besprekornim jezikom i stilom, a ujedno su i idejno dobro postavljene. Kako je do sada, službom pravnog referenta u Ministarstvu financija NR Hrvatske bio spriječen u intenzivnom radu, on je dao ostavku i želi da se sav posveti književnom radu. Mislim da bi ga trebalo pomoći u tom nastojanju i time da bude primljen za člana DKH. Kako je za kandidata prestar i kako se i ovim malim do sada radom afirmirao kao zreo pisac, mislim da bi trebao biti primljen samo kao redovan član Društva. S. F - S. N! Slavko Kolar. ${ }^{5}$

Kao prilog ovom Kolarovom obrazloženju i odluci Društva književnika Hrvatske, na zahtev Saveza književnika Jugoslavije Desnica je priložio svoju kratku biografiju, koju je pisao u trećem licu. Ova biografija sačuvana je u kartoteci književnika pri Savezu književnika Jugoslavije, ${ }^{6}$ i to je u stvari onaj životopis čija se kopija čuva u Desničinoj zaostavštini, u kutiji pod odrednicom „Izdavački ugovori, razni curriculum-i vitae i notices sur l'auteur iz raznih pera"7 Svoj životopis Desnica je otpočeo osnovnim biografskim podacima:

glasnost za pokretanje postupka prijema u članstvo. Tek kada je Savez književnika Jugoslavije 20. juna 1950. godine dao načelnu saglasnost (ali uz opasku da "Savez mora biti obaveštavan o svakom koraku u tom pravcu“), Društvo književnika Hrvatske moglo je da pristupi proceduri. Znakovito je, takođe, što je u ovakvim, „osetljivim“ slučajevima, sam Savez književnika Jugoslavije odlučivao ko će od članova republičke organizacije (u ovom slučaju hrvatske) razgovarati s kandidatom i pisati preporuku. U Ujevićevom slučaju Savez književnika Jugoslavije odredio je da to bude Novak Simić - v. AJ 498-F-69.

AJ 498-F-73.

AJ 498-F-98.

V. Drago Roksandić, „Kud koje žure brzi kraci / a vode svi u bespuće: Vladan Desnica u Splitu od 1935. do 1941. godine“, u: Split i Vladan Desnica 1918.-1945.: umjetničko stvaralaštvo izmedu kulture i politike (ur. Drago Roksandić i Ivana Cvijović Javorina), Zagreb 2015., 416. 
DESNICA Vladan, Urošev.

Rođen u Zadru, 17. septembra 1905.

Oženjen, četvero djece.

Narodnost srpska, državljanstvo NRH.

Adresa: Zagreb, Kraševa ul. 14/1.

Matura klasične gimnazije (u Šibeniku, 1924), diplomirao Pravni fakultet u Zagrebu (1929. ili 1930). Bio upisan i na Filozofski fakultet u Zagrebu, slušao slobodne tečajeve povijesti i teorije umjetnosti u Parizu.

Ranije službenik Drž. Pravobranilaštva u Splitu, poslije Oslobođenja šef Pravnog odsjeka Ministarstva financija NRH u Zagrebu, sada se posvetio isključivo književnosti.

Potom je u trećem licu jednine (osim u završnom delu životopisa) predstavio, naglašeno skromno, svoj dotadašnji književni rad. Tako kaže da je „vrlo malo objavljivao“, svoje studije o Dositeju Obradoviću i Mirku Koroliji naziva „esejčićima“, a da je prevod Kročea „možda vrijedan pomena“. S obzirom na posleratnu ideološku klimu, nije čudno što Desnica ističe kako „za vrijeme okupacije nije objavljivao ništa“.

Na sednici Saveza književnika Jugoslavije održanoj 2. aprila 1950. godine predlog je jedinstveno prihvaćen, i o tome je obavešteno Društvo književnika Hrvatske. ${ }^{9}$ U tom kratkom dopisu stoji da se „Vladan Desnica od datuma naznačenog u ovom dopisu [2. IV 1950., prim. B. Đ.] ima smatrati punopravnim članom Saveza književnika Jugoslavije, a samim tim i Društva književnika Hrvatske." Dakle, formalnopravno gledano, Desnica je član republičke i savezne strukovne organizacije postao početkom aprila 1950. godine!

\section{2.}

Od samoga učlanjenja u republičku i saveznu strukovnu organizaciju Vladan Desnica se predano zalagao za zaštitu socijalnih prava književnika. Bio je jedan od potpisnika primedbe na ugovor o socijalnom osiguranju književnika, koji je sklopljen između Saveza književnika Jugoslavije i Saveta za narodno zdravlje i socijalnu zaštitu FNRJ. Primedba je na sednici Upravnog odbora Društva književnika Hrvatske usvojena 12. januara 1953., a na sednici Upravnog odbora Saveza književnika Jugoslavije 30. januara 1953. godine. ${ }^{10}$

Druga akcija u kojoj je učestvovao i Vladan Desnica - i čak bio jedan od pokretača i najvidniji eksponent - takođe se ticala važnog esnafskog pitanja, zadirući - u osetljivo vreme tek započete liberalizacije u kulturi - u pitanje dostojanstva spisateljske profesije. Radilo se, naime, o zahtevu grupe hrvatskih književnika da im se, za priloge objavljene u almanahu Poezija - proza 1952, isplati honorar. Almanah Saveza književnika Jugoslavije, koji se pojavio 1953. godine, osmišljen je kao svojevrsna antologija najboljih pripovedaka, novela i pesama koje su objavljene prethodne, 1952. godine, u drugim novinama i časopisima. Tako je Desničina pripovetka Formalista, koja je uvrštena u almanah, ${ }^{11}$ objavljena pre to-

\footnotetext{
D. Roksandić čak misli da je ovaj životopis pisan pomalo „s autoironijske distance“ (Isto, 417).

AJ 498-F-73.

10 AJ 498-F-71.

11 Vladan Desnica, „Formalista“, Poezija - proza 1952, Beograd 1953., 94-101.
} 
ga u časopisu Hrvatsko kolo. ${ }^{12}$ Neprijatnu dužnost da se pravda pred rukovodstvom Saveza književnika Jugoslavije imao je tadašnji sekretar Društva književnika Hrvatske Novak Simić. On je protestovao kod Aleksandra Vuča zbog toga što je Borislav Mihajlović Mihiz u $N I N$-u, prikazujući almanah, naglasio da su se svi pisci odrekli honorara. Simić je, međutim, 5. decembra 1953. godine dostavio spisak članova Društva književnika Hrvatske koji su tražili da im honorar bude isplaćen. Na tom spisku bio je i sam Novak Simić, a pored njega još i Ranko Marinković, Mirko Božić, Vladan Desnica, Vojin Jelić, Stanislav Šimić, Šime Vučetić, Vjekoslav Majer, Boro Pavlović, Drago Ivanišević, Radovan Ivšić, Vladimir Popović i Gustav Krklec. Njihovi potpisi stajali su uz pismo upućeno Predsedništvu Saveza književnika Jugoslavije. Ono što je značajno jesu Simićeve reči da je to pismo sa zahtevom za isplatu honorara „uobličio i dao mu konačnu formu“ Vladan Desnica, a da su se drugi složili sa Desničinim tekstom i potpisali ga! Kao čovek koji se odlučio za rizičnu profesiju tzv. slobodnog umetnika, kako se tada to zvalo, Desnica je umeo da obrazloži zahtev, znajući očigledno da će to naići na odijum kod mnogih njegovih kolega po peru:

Treba imati na umu da dobar dio pisaca iz Hrvatske jesu profesionalni književnici, koji žive isključivo od svog literarnog rada, a da golema većina onih, koji su namješteni, imaju nedovoljne prihode, ili porodice koje uzdržavaju. Smatramo, ujedno, da bi odricanje od honorara učinilo jedan vrlo opasan presedan za kojim bi se mogli u sličnim i analognim slučajevima povesti i mnogi drugi izdavači. Smatramo i to, da se time vrši presija onih pisaca, koji su ekonomski osigurani, na svoje siromašnije drugove. ${ }^{13}$

Uz to je Desnica istakao činjenicu koja dosta govori o ondašnjim različitim kulturnim prilikama u Jugoslaviji. On je, naime, ovaj zahtev obrazložio i činjenicom da su pisci iz Beograda u mnogo povoljnijem položaju - knjige u beogradskim knjižarama imaju veću cenu nego u Zagrebu, honorari su veći, veći je i tiraž, a pritom je cena štamparskih usluga za četvrtinu niža nego u Hrvatskoj..$^{14}$

O ovom pitanju, ali i o samoj koncepciji Almanaha, raspravljalo se na 10. Plenumu Saveza književnika Jugoslavije, održanom u Beogradu 28. i 29. januara 1954. godine. Najpre je Aleksandar Vučo objasnio kako se sakupljaju tekstovi za almanah. Njih su odabirali članovi republičkih komisija, a zatim ih slali Centralnoj komisiji Saveza književnika Jugoslavije (članovi te komisije su bili Aleksandar Vučo, Petar Šegedin i Novak Simić). Vučo se zatim osvrnuo na pitanje honorisanja tekstova:

...Što se tiče autorskog honorara, Savez je bio mišljenja da bi naši članovi trebalo da ga se odreknu, s obzirom na važan i plemeniti cilj ovakve jedne publikacije... I drug Bogdanović [Milan Bogdanović, prim. B. Đ.] je i na 9. Plenumu naglasio da bi trebalo da se pisci, čiji se tekstovi izaberu za takav jedan almanah, odreknu svojih honorara, jer i pisci, sa svoje strane, treba da osete to kao opšti zajednički posao i jer je, u krajnjoj liniji, u interesu svih pisaca da se takav jedan almanah pojavi. Međutim, Plenum nije doneo obavezujuću odluku da se radovi u almanahu ne honorišu..$^{15}$

\footnotetext{
12 Isti, „Formalista“, Hrvatsko kolo, V/1952., br. 1, 7-12. Za ovu pripovetku Desnica je od Društva književnika Hrvatske nagrađen sa 100.000 dinara, o čemu je ovo udruženje 12. maja 1953. godine obavestilo Savez književnika Jugoslavije - v. AJ 498-F-71.

13 AJ 498-F-71.

14 Isto.

15 AJ 498-F-13.
} 
Tu odluku je, naime, Plenum prepustio Izvršnom odboru Saveza književnika Jugoslavije, a ovaj ju je elegantno otklonio, ,jer članovi Izvršnog odbora nisu hteli da odlučuju bez prethodnog konsultovanja svih udruženja, odnosno svih autora čiji su radovi objavljeni u almanahu“. 16

U diskusiji koja se na Plenumu povela većina književnika je osuđivala ovaj zahtev grupe pisaca iz Hrvatske. Sam Aleksandar Vučo okrivio ih je da je, zbog njihovih zahteva, cena almanaha veća nego što je bilo predviđeno. Vlatko Pavletić je dodao da je zahtev ovih pisaca uneo nemir među članove Društva književnika Hrvatske i da su „duhovi bili dosta uznemireni“, pa zbog toga Društvo hrvatskih književnika nije zauzelo jedinstven stav u odnosu na almanah i na pitanje honorara. Svoje kolege oštro je osudio i Petar Šegedin, na šta mu je Novak Simić zamerio što se on sam nije odrekao honorara kao „dvostruki član komisije za izbor tekstova - i republičke i centralne“. Milan Bogdanović je rekao da se pisci čiji su tekstovi ušli u Almanah ne mogu smatrati saradnicima, „nego su njihova dela izabrana i štampana u almanahu“. Posebno rezolutan i gnevan bio je Dušan Matić:

Trebalo bi tom drugu... kako beše (neko dobacuje: Desnici)... trebalo bi mu biti jasno da je udruživanje jedno pravo, a kad ljudi uđu u udruženje, oni moraju i nečeg da se odreknu, inače onda oni stupaju u udruženje samo zato da uzimaju.

Uz to je Matić, ironično, predložio da se ovim piscima isplati simbolični honorar od dva dinara.

Pored Novaka Simića, koji je branio zahtev pisaca iz Hrvatske, na ovom stanovištu bio je i Ivan Dončević, koji je istakao da „nikakav forum nema pravo da nekog prisiljava da se odrekne honorara, ako on to neće. To je apsurd.“ Mirko Božić je tvrdio to isto, uz to napominjući da su se i srpski i hrvatski pisci već odrekli honorara za prevod svojih tekstova u makedonskom i slovenačkom izdanju almanaha. ${ }^{17}$

Najzad je Plenum doneo odluku da se književnicima koji su to zahtevali honorar isplati, ali da on bude obračunat po najnižoj tarifi, koja je vredela za tekstove objavljene u čitankama. ${ }^{18} \mathrm{Na}$ osnovu ove odluke Vladanu Desnici je 10. februara 1954. godine isplaćeno 7.900 dinara. ${ }^{19}$

Drugi deo rada Plenuma odnosio se na koncepciju Almanaha. Jedni su ga branili, drugi napadali. Iz dva suprotstavljena tabora čula su se dva glasa koja su eksplicitno pominjala Vladana Desnicu, to jest njegovu pripovetku objavljenu u Almanahu. Tako je Oskar Davičo oštro kritikovao koncepciju Almanaha, predlažući da se on više u tom obliku ne izdaje:

Almanah je potpuni promašaj. Nema nikakvu tendenciju niti ideju-vodilju, nema određeni cilj i određeni zadatak. Ne treba štampati almanah radi dva-tri dobra priloga, kao što je onaj Vladana Desnice. ${ }^{20}$

\footnotetext{
16 Isto.

17 V. Isto, Zapisnik sa 10. Plenuma Saveza književnika Jugoslavije.

18 Isto.

19 AJ 498-F-71.

20 AJ 498-F-13.
} 
Ivo Andrić, pak, svim se srcem zalagao za Almanah, obrazlažući to potrebom da se na jednom mestu skupe tekstovi inače razbacani po raznim novinama i časopisima, nakon čega je usledila eksplicitna pohvala Desničine pripovetke:

Ja sam apsolutno za almanah. Almanah je tableau naše književnosti u jednoj godini. $\mathrm{O}$ almanahu loše govore pisci čiji radovi nisu ušli u njega. Ja lično ne mogu stići da čitam sve novine i časopise i da pratim sve što se objavljuje. I eto, da nije almanaha, ne bih znao da je ovaj Desnica toliko već iskusan i izvanredan pisac. ${ }^{21}$

\section{3 .}

Kritički tonovi na račun Vladana Desnice stizali su, u principu, samo iz njegovog matičnog udruženja, dakle Društva književnika Hrvatske. Tako je 14. januara 1955. godine komisija Društva književnika Hrvatske, kojoj je predsedavao Jože Horvat, poslala Savezu književnika Jugoslavije „spisak onih članova DKH koji u 1954. godini nisu sudjelovali u društveno korisnim poslovima (uredništvo, bibliografije, književne večeri, posete preduzećima, pomaganje raznim savezima poput Saveza lovačkih društava, i sl.)“. Na prvom mestu je Vladan Desnica! ${ }^{22}$

Ipak, Desnica je bio delegat Društva književnika Hrvatske na tri kongresa Saveza književnika Jugoslavije. Prvi put je učestvovao na Četvrtom kongresu, održanom od 15. do 17. septembra 1955. godine u Ohridu. Podaci koji se čuvaju u fondu Saveza književnika Jugoslavije ${ }^{23}$ govore, bar kada je o Desnici reč, o osnovnim činjenicama toga njegovog učešća: kako je putovao (došao je, najpre, iz Zagreba u Beograd, a odatle se odvezao u Ohrid, 13. septembra, specijalnim avionom koji je za svoje članove zakupio Savez književnika Jugoslavije), gde je bio smešten (u Domu „Orce Nikolov“, u sobi 37, zajedno sa Radovanom Ivšićem), kolike su bile dnevnice (primio je za tri dana 1.900 dinara).

Slični podaci čuvaju se i kada je u pitanju Desničino učešče na sledećem, Petom kongresu Saveza književnika Jugoslavije, održanom od 25. do 28. novembra 1958. godine u Beogradu. ${ }^{24}$ Stigao je vozom 24. novembra, odseo u hotelu „Moskva“ (u sobi 47), a hranio se, kao i drugi književnici, u tadašnjem restoranu „Dušanov grad“ na Terazijama. No, jedan drugi podatak mnogo je zanimljiviji. Naime, iako nije bio diskutant na Kongresu, Desnica se ipak oglasio, i to prvoga dana. Posle otvaranja Kongresa delegati su otišli do Saborne crkve u Beogradu, gde su položili vence na grobove Vuka Karadžića i Dositeja Obradovića. Tom prilikom održane su dve besede u slavu ovih velikana srpske književnosti. O Vuku je govorio Ivo Andrić, a o Dositeju Vladan Desnica. Besede nisu sačuvane, ali se čini da ne bi bilo daleko od istine kada bismo pretpostavili da je Desnica tada pročitao odlomak iz svog predratnog eseja o Dositeju Obradoviću.

\footnotetext{
21 Isto.

22 AJ 498-F-71. Može nas začuditi što je među „raznim savezima“ istaknut baš Savez lovačkih društava, ali to biva jasnije kada se zna da je predsednik toga saveza bio upravo Joža Horvat. Tako se i na ovaj način, sitnim smicalicama, nastavljao Horvatov obračun sa Desnicom otpočet 1950. godine kritikom Zimskog ljetovanja.

23 AJ 498-F-1.

24 Isto.
} 
Desnica je učestvovao još i na Šestom kongresu Saveza književnika Jugoslavije, održanom u Sarajevu od 16. do 18. septembra 1961. godine. O Desnici, međutim, nema pomena u dokumentima sa ovog kongresa, sem njegovog imena na spisku delegata. ${ }^{25}$ To što Desnica nije bio delegat na Sedmom kongresu Saveza književnika Jugoslavije, održanom od 24. do 26. septembra 1964. godine u Titogradu, može se verovatno objasniti njegovim pogoršanim zdravstvenim stanjem.

\section{4 .}

U dokumentima pohranjenim u fondu Saveza književnika Jugoslavije nalaze se i podaci o priznanjima i nagradama koje je Desnica za svoje književno svaralaštvo dobijao. Godine 1953. Desnica se našao u grupi prvih dobitnika tek ustanovljene nagrade Saveza književnika Jugoslavije za književna dela objavljena u prethodnoj godini. Pored nagrade za životno delo, dodeljene Miroslavu Krleži, nagrade su dodeljene za najbolji roman (Oskaru Daviču za roman Pesma), najbolju knjigu kritika (Milanu Bogdanoviću za knjigu Stari i novi IV) i za zbirku pripovedaka. U ovoj poslednjoj konkurenciji žiri (koji su činili Milan Bogdanović iz Srbije, Jure Kaštelan iz Hrvatske, Filip Kalan Kumbatovič iz Slovenije, Marko Marković iz Bosne i Hercegovine i Dimitar Mitrev iz Makedonije) odlučio se za Desničinu zbirku Olupine na suncu (u najužoj konkurenciji bile su i knjige Eriha Koša Vreme: ratno i Novaka Simića Druga obala). Novčani iznos ove nagrade bio je sto hiljada dinara. ${ }^{26}$

No, kada je sa sledećom svojom knjigom konkurisao, ovoga puta za nagradu Društva književnika Hrvatske, Vladan Desnica morao se uveriti da omraza prema njemu nije niukoliko prestala, da se samo čekalo na prvi povod da opadanja i spletke ponovo počnu. $U$ najopsežnijoj Desničinoj biografiji, onoj koju je sačinio Dušan Marinković, čita se:

Iste [1956., prim. B. Đ.] godine izlazi u izdanju Matice srpske u Novom Sadu Tu, odmah pored nas: priče o proljeću, ljubavi i smrti, i za nju dobiva nagradu Društva književnika $\mathrm{Hr}$ vatske. Žiri je radio u sastavu: Drago Ivanišević, Ivo Frangeš i Novak Simić. Ovom zbirkom Desnica se uvrštava među najbolje noveliste u srpskoj i hrvatskoj književnosti, što je književna kritika prepoznala is neskrivenim priznavanjem isticala. ${ }^{27}$

Tačno je da je bilo veoma pohvalnih kritika, poput one Dragomira Kastratovića u Vjesniku ili Vladimira Bunjca u Delu, ali zahvaljujući jednom Desničinom pismu sada znamo da ni ovog puta nije prošlo bez pokušaja da se Desnica degradira i odstrani iz konkurencije. Jednostavno rečeno, Desnica je optužen da je njegova nova zbirka, Tu, odmah pored nas, zapravo kompilacija već objavljenih pripovedaka i novela, i da stoga ne može ući u konkurenciju za nagradu Društva književnika Hrvatske. Desnica se, tim povodom, obratio pismom Aleksandru Vuču, generalnom sekretaru Saveza književnika Jugoslavije. Pismo je otposlao 17. maja 1954. godine i, kao što se može videti, ono je pisano u izrazito prijateljskom tonu,

25 Isto.

26 AJ 498-F-68. Inače, ova nagrada dodeljena je samo četiri puta. Godine 1957. nije bilo novca i došlo je do prekida, a od 1960. godine dodeljivana je samo za životno delo.

27 D. Marinković, „Biografija Vladana Desnice“, 242. 
uz implicitnu molbu za pomoć. Uprkos suzdržanosti i nastojanju da se bude objektivan, vidi se da Desnica nije mogao da sakrije svoju uvređenost, pa i ljutnju, svestan da „podzemni“ napadi na njega ne prestaju već šestu godinu:

Dragi Aco,

Prilikom zasjedanjâ, pretresanjâ i odlučivanjâ o raznim nagradama, s čudnom upornošću servira se jedna činjenična dezinformacija koja me sili da iziđem iz rezerve i da ti uputim ovih nekoliko riječi nužnih objašnjenja. Mojoj najnovijoj knjizi TU, ODMAH PORED NAS prikrpljena je, ne znam otkud, etiketa „retrospektivnosti“, a ispod ruke potura se da je ona, pod drugim naslovom ili u nešto drukčijem sastavu, već jednom nagrađena. Ta mahlojka, dosad upotrebljena u dva maha, postigla je željeni rezultat, kao što se možeš osvjedočiti i iz novinskog istriška koji ti prilažem. Vjerujem da čitav moj habitus i stil postupanja dovoljno svjedoče koliko mi je strano svako laktašenje, ali čovjeka čisto revoltira ovakvo očito falsificiranje golih činjeničnih podataka. OLUPINE NA SUNCU, izdane 1952., pretstavljaju moju prvu knjigu pripovijedaka, a TU, ODMAH PORED NAS, izd. 1956., drugu, potpuno novu knjigu, koja sadrži 16 novela napisanih mahom poslije 1953. god. Od tih 16 novela samo tri su ušle u izbor koji mi je izdala „Prosveta“ pod naslovom PROLJEĆE U BADROVCU, ali ni ta okolnost, pošto taj izbor nije nagrađen, ne može da ima uticaja. Prema tome, ne postoji baš nikakva formalna zapreka da knjiga TU, ODMAH PORED NAS bude uzeta u razmatranje, a još manje osnov da joj se prišiva etiketa „retrospektivnosti“. Knjiga koja donosi novele kao Solilokvij g. Pinka, Spiriti, Šarasta kutijica i dr. može da bude u meritumu pronađena nedostojna nagrade koliko god se to hoće, ali ne treba dozvoliti da se operira formalnim smicalicama koje se osnivaju na flagrantnim dezinformacijama i očitom izvrtanju fakata. Ističem, niukoliko ne želim uticati na sam meritorni sud o mojoj knjizi. Bio bih veoma zadovoljan kad bih sigurno znao da su je pročitali oni koji o njoj imaju da odluče. Ne pretendiram čak ni na to da se ovi moji činjenični navodi prime za gotovo; neka ti samo budu poticaj da se na svoju ruku informišeš i utvrdiš pravo stanje stvari. Žalim što ti, mjesto o čemu pametnijem, silom prilika moram da pišem o ovakvim tugaljivim temama. A ni pored toga ne bih to činio, kad ne bih imao punu vjeru u tvoju objektivnost i lojalnost. Sa srdačnim pozdravom i prijateljstvom tvoj Vladan Desnica [svojeručni potpis, prim. B. Đ.]. ${ }^{28}$

Da se Desnica očigledno obratio na pravu adresu govori najpre Vučova beleška koja svedoči da se on odmah angažovao na ispravljanju ove nepravde: „Razgovarao sa onima iz DKH. Javio Desnici da je ova svinjarija anihilirana." ${ }^{29}$ Još više o tome svedoči odluka žirija Društva književnika Hrvatske da Desničinoj zbirci novela Tu, odmah pored nas dodeli nagradu DKH i 100.000 dinara, o čemu je obavešten i Savez književnika Jugoslavije. ${ }^{30}$

Da je Vladan Desnica u Savezu književnika Jugoslavije sve vreme posmatran kao jedan od najboljih jugoslovenskih pisaca svedoči i to što se vrlo često nalazio među onim književnicima čija su dela predlagana za prevođenje u inostranstvu, kao „najbolji reprezenti naše umetnosti i kulture uopšte“.31 Imajući u vidu činjenicu da je Desničin pesnički opus 
potisnut u stranu prilikom vrednovanja njegovog sveukupnog književnog dela (iako je u molbi za prijem u Savez književnika Jugoslavije Desnica kao vredne pažnje istakao i svojih „nekoliko lirika“), vredi istaći da je Savez književnika Jugoslavije italijanskom Književnom društvu za svojevrsnu antologiju jugoslovenske poezije, među devet odabranih pesnika, za prevođenje predložio i pesme Vladana Desnice. ${ }^{32}$ Te pesme pojavile su se u listu Il Giornale dei poeti, početkom 1958. godine. ${ }^{33}$

Tri godine docnije, u okviru tzv. prevodilačke razmene, Savez književnika Jugoslavije za prevod je Sovjetskom udruženju pisaca predložio šest jugoslovenskih romana, među njima i Desničin roman Proljeća Ivana Galeba. ${ }^{34}$

Da je Desnica bio izuzetno cenjen i svrstavan u red najboljih jugoslovenskih književnika svedoči i poziv za gostovanje na Kanarskim ostrvima. Naime, potpredsednik Udruženja pisaca Španije, T. Fuentes, obratio se Komisiji Federativne Narodne Republike Jugoslavije za kulturne veze $s$ inostranstvom, sa pozivom da nekoliko jugoslovenskih književnika gostuje na književnom festivalu na Kanarskim ostrvima. Komisija za kulturne veze s inostranstvom se 1. marta 1954. godine obratila Savezu književnika Jugoslavije s molbom da odredi „najreprezentativnije pisce“, a iz Saveza književnika Jugoslavije odgovoreno je „da to treba da budu najbolji naši književnici“, i zbog toga su predloženi „drugovi Miroslav Krleža, Ivo Andrić i Vladan Desnica“. ${ }^{35}$ Kao što se i iz ovoga vidi, polako se stvarala slika o trojici velikana jugoslovenske književnosti, u čiji ram je bio uvršten i Desnica, inače desetak godina mlađi od Krleže i Andrića. Tek će povratak Crnjanskog u Jugoslaviju, i njegovi novi romani, doprineti da ta slika u svesti docnijih naraštaja bude drugačija.

Poslednji spomen Vladana Desnice u dokumentima Saveza književnika Jugoslavije jeste popis članova, koji je Društvo književnika Hrvatske Savezu književnika Jugoslavije dostavilo 1965. godine. U tome popisu, pod rednim brojem 27, navedeno je ime Vladana Desnice. Na tom istom popisu, uz Desničino ime je neko iz Saveza književnika Jugoslavije, dve godine docnije, birokratski šturo i neumoljivo, crvenim mastilom, zapisao: „Umro 4. marta 1967.“36 To je, tada, bilo koliko činjenično stanje, toliko i najnužniji biografski podatak - najmanje i najviše što se o Desnici kao članu jedne strukovne organizacije moglo reći. Da bi se, od tada, o njemu moglo govoriti suštinski - kao o čoveku iza kojeg stoji dragoceno književno delo.

32 AJ 498-F-71.

33 Savez književnika Jugoslavije je 9. maja 1958. godine primio deset primeraka ovog časopisa, jedan za Savez, a devet da se proslede pesnicima čiji su stihovi prevedeni i objavljeni - v. isto.

34 Pored Desničinog romana predloženi su i romani Crveni petao leti prema nebu Miodraga Bulatovića, Beton i svici Oskara Daviča, Deobe Dobrice Ćosića, Raspust Aleksandra Vuča i Hajka Mihaila Lalića - v. AJ 498-F-72 (18. 4. 1961.).

35 V. AJ 498-F-69.

36 AJ 498-F-73. 


\section{$\cos$}

\section{Vladan Desnica in the documents of the Union of YugOSLAV WRITERS}

Vladan Desnica was a member of the Union of Yugoslav Writers since April 1950. From the very beginning of his membership in this professional organization active on the republic and federal levels, Vladan Desnica was dedicated to the protection of the social rights of the writers. He was one of the signatories of the comments on the agreement on the writers' social security that was concluded between the Union of Yugoslav Writers and the Council of Public Health and Social Welfare of the Federal People's Republic of Yugoslavia. Desnica was also one of the initiators, and the most visible proponent, of another important welfare-related effort that had to do with the dignity of the writing profession at a sensitive time when first efforts at liberalization were made in the field of culture. The issue was that a group of Croatian writers demanded a fee for their work published in the Poezija-proza 1952 almanac. Desnica served as a delegate of the Croatian Writers' Association to three congresses of the Union of Yugoslav Writers: those in Ohrid 1955, Belgrade 1958 and Sarajevo 1961. In Belgrade he gave a eulogy on the grave of Dositej Obradović before the Union of Yugoslav Writers.

Desnica's works were often suggested for translation into foreign languages as "the best representation of our art and culture in general", which attests to the fact that, within the Union, he was uniformly regarded as one of the best Yugoslav writers. At one point, faced with accusations from his parent organization, the Writers' Association of Croatia, Desnica turned to the Union of Yugoslav Writers and its secretary Aleksandar Vučo for help, which he ultimately received. Therefore, although Desnica's participation in the work of the Union of Yugoslav Writers was only sporadic, it does serve to illuminate some moments from the writer's literary biography.

Key words: Vladan Desnica, the Union of Yugoslav Writers, writers' congresses, Almanac, cultural politics

\section{$\cos$}

\section{Izvori}

Arhiv Jugoslavije, Fond Saveza književnika Jugoslavije (498)

Poezija - proza 1952. Almanah Saveza književnika Jugoslavije, Beograd 1953., 94-101.

\section{Literatura}

Dušan Marinković, „Biografija Vladana Desnice“, u: Vladan Desnica, Hotimično iskustvo (prir. Dušan Marinković), Zagreb 2006., 217-250.

Drago Roksandić, „Kud koje žure brzi kraci / a vode svi u bespuće: Vladan Desnica u Splitu od 1935. do 1941. godine“, u: Split i Vladan Desnica 1918.-1945.: umjetničko stvaralaštvo između kulture i politike (ur. Drago Roksandić i Ivana Cvijović Javorina), Zagreb 2015., 415-458. 